\title{
Attendance in Physical Education classes and associated factors among high school students
}

\author{
Participação nas aulas de Educação Física e fatores associados em estudantes do \\ ensino médio
}

\begin{tabular}{l} 
AUTHOR'S \\
\hline Alcides Prazeres Filho ${ }^{1,2}$ (D) \\
Gerfeson Mendonça ${ }^{2,3}$ (D) \\
João Miguel Souza Neto ${ }^{2}$ (D) \\
Rafael Miranda Tassitano ${ }^{4}$ (D) \\
Anderson Barbosa Paiva Silva (D) \\
José Cazuza de Farias Júnior ${ }^{1,2,5}$ (D) \\
1 Post-Graduation Associated Program in Physical \\
Education - UPE/UFPB, Department of Physical \\
Education, João Pessoa, Paraíba, Brazil. \\
2 Research and Study Group in Epidemiology of \\
Physical Activity - GEPEAF, João Pessoa, Paraíba, \\
Brazil. \\
3 University Center Cesmac, Maceió, Alagoas, \\
Brazil. \\
4 Rural Federal University of Pernambuco, \\
Department of Physical Education, Recife, \\
Pernambuco, Brazil. \\
5 Federal University of Paraíba, Department of \\
Physical Education, João Pessoa, Paraíba, Brazil.
\end{tabular}

\section{CORRESPONDING}

Alcides Prazeres Filho

alcidespf@hotmail.com

Federal University of Paraíba, Department of Physical Education Campus I, Cidade Universitária, João Pessoa, Paraíba, Brazil. ZIP Code: 58059-900.

\section{DOI}

10.12820/rbafs. $24 \mathrm{e} 0083$

\section{(cc) BY-NC-SA}

This work is licensed under the Creative Commons Attribution-NonCommercial-ShareAlike 4.0 International License.

\begin{abstract}
This study examined the prevalence of attendance in Physical Education (PE) classes and associated factors among high school students. A cross-sectional study performed with 2,874 public and private high school students ( $57.9 \%$ girls, mean age of 16.45 years; $\mathrm{SD}=1.22)$ from João Pessoa, Paraíba, Brazil. Attendance in PE classes was measured by the question: 'How many PE classes do you attend during a normal week? The factors measured were: attitude, self-efficacy, risks and benefits related to physical activity (PA), perceived health, PA level, sedentary behavior and nutritional status. Binary logistic regression was used. It was observed that $41.9 \%$ attended two or more PE classes per week, with higher prevalence rates in public school students than private school counterparts $(56.6 \%$ vs. $6.6 \% ; \mathrm{p}<0.001)$. Higher attendance in PE classes was observed in male and younger students from both school systems. It was also observed in students who did not work, were members of the highest economic class and whose parents had higher schooling levels in public schools, and from $1^{\text {st }}$ and $2^{\text {nd }}$ grades of high school education in private institutions. Attending two or more PE classes per week is positively associated with a more favorable attitude to engaging in PA as well as its level, in both school systems, and with positive health perception among public students. In conclusion, attendance in PE classes was low, particularly in private schools. Attending two or more PE classes per week was associated with positive aspects of $\mathrm{PA}$ and health in the students under study.
\end{abstract}

Keywords: Physical education; Adolescent; Motor activity; School health; Motivation.

\section{RESUMO}

O presente estudo determinou a prevalência de participação nas aulas de Educação Física (EF) e analisou fatores associados em estudantes do ensino médio. Estudo transversal com 2.874 estudantes do ensino médio das redes pública e privada (57,9\% feminino, média de idade = 16,45 anos; $D P=1,22)$ de João Pessoa, Paraíba, Brasil. A participação nas aulas foi mensurada pela pergunta: 'Durante uma semana normal, em quantas aulas de EF você participa?'. Os fatores mensurados foram: atitude, autoeficácia, riscos e benefícios relacionados à prática de atividade física $(A F)$, percepção de saúde, nível de $A F$, comportamento sedentário e estado nutricional. Foi utilizada regressão logistica binária. Observou-se que $41,9 \%$ dos estudantes participavam de duas aulas ou mais de EF por semana, sendo maior nas escolas públicas comparado às privadas (56,6\% vs. 6,6\%; $p<0,001)$. Uma maior participação nas aulas foi identificada nos estudantes do sexo masculino e mais jovens de ambas redes de ensino, nos estudantes da rede pública que não trabalbavam, de classe econômica mais alta e com maior escolarização dos pais, e naqueles da rede privada das $1^{a}$ e $2^{a}$ séries do ensino médio. Participar de duas ou mais aulas de EF por semana foi positiva e significativamente associada com atitude mais favorável à prática e ao nivel de $A F$ dos estudantes; e com percepção positiva de saúde nos estudantes da rede pública. A participação nas aulas de EF foi baixa, particularmente na rede privada. Participar de duas ou mais aulas de EF por semana se associou a aspectos positivos em relação à $A F$ e à saúde dos estudantes.

Palavras-chave: Educação Física; Adolescente; Atividade motora.

\section{Introduction}

According Worldwide Survey of School Physical Education (PE) - Final Report 2013, PE is a mandatory curricular component of basic education in several countries $^{1}$. In Brazil, the Law of National Guidelines and Bases of National Education - $\mathrm{LDB}^{2}$ made PE mandatory for elementary and secondary students, except for those who work six or more hours a day, persons aged 30 years or older, armed forces personnel, those with chronic diseases or disorders, and female students with children ${ }^{2}$.

The quality of PE report of United Nations Educational, Scientific and Cultural Organization (UNES$\mathrm{CO}$ ) suggests this discipline is a basic right and should 
be an important part of the educational system. In addition, it is an essential component for empowering an active and healthy lifestyle ${ }^{3}$ and contributing to the development of biological, affective, cognitive, motor and sociocultural aspects of human movement.

Previous state and municipal surveys have reported low attendance in PE classes, such as Pernambuco $-33.1 \%{ }^{4}$, Santa Catarina - 58.8\% ${ }^{5}$, São Paulo city (São Paulo) - 49.5\% $\%^{6}$, Londrina (Paraná) $-72.9 \%^{7}$ and Aracaju (Sergipe) $-79.5 \%{ }^{8}$. According to UNESCO reports $^{3}$, this problem is not confined to Brazil, but prevalent worldwide. The scenario can be even more worrisome if the effective attendance of students is considered $^{6}$.

Attending PE classes has been associated with less exposure to sedentary behaviors ${ }^{9}$, higher levels of physical activity ${ }^{4,7}$, greater participation in sports ${ }^{7}$, healthy eating habits ${ }^{4}$ and lower likelihood of consuming legal and illegal drugs ${ }^{5}$. Self-efficacy ${ }^{10}$, positive attitudes toward physical activity ${ }^{1}$ and perceived risks and benefits of physical activity ${ }^{10}$ are factors linked to physical activity in adolescents. Thus, attending PE classes may be associated with these factors in students.

However, important knowledge gaps persist, regarding high school student attendance in PE classes and their distribution in public and private schools; the association between attending these classes and behavioral factors, physical activity correlates, nutritional status and perceived health status.

Information on student attendance in PE classes may help identify groups with lower attendance and increase knowledge about the possible benefits associated with attending these classes. Thus, the aim of this study was to determine the prevalence of PE class attendance and analyze the association with physical activity level, sedentary behavior, correlates of physical activity, nutritional status, and perceived health status among public and private high school students in Northeastern Brazil.

\section{Methods}

This cross-sectional epidemiological study was conducted with data from a representative sample of public and private high school students in João Pessoa, Paraíba, Northeastern Brazil, in 2009. The reference population of 32,112 high school students, given the multiple outcomes of the project was considered to determine sample size prevalence estimated at 50\%; maximum error of three points percentage points; $95 \%$ confidence interval; design effect (deff) of two; and 30\% increase in the minimum sample size to compensate for losses and refusals, resulting in a sample of 2,686 students.

In the first stage, of the 82 existing schools in the municipality, 30 schools were systematically selected, distributed proportionally by size (number of students enrolled), type (16 public and 14 private) and geographic location (north, south, east and west). In the second, 135 classes were randomly selected (based on an estimated 20 students per class), distributed according to the proportion of students enrolled per grade $\left(1^{\text {st }}\right.$, $2^{\text {nd }}$ and $3^{\text {rd }}$ grade) and study shift (morning, afternoon and night). Adolescents who did not provide written informed consent were considered sample losses. Exclusion criteria were adolescents outside the established age range (younger than 14 and older than 19), any impairment that hindered or limited physical activity and/ or prevented them from completing the questionnaire.

Data collection was carried out between May and September 2009 by a team of six previously trained PE students submitted to a pilot study under the same conditions as the primary study. The students who were present for at least one of two data collection team visits responded to the questionnaire during regular class time, in the form of a collective interview (mean duration of 25 minutes per application).

The sociodemographic variables measured were sex (male and female), age in years and later categorized (14-15 and 16-19 years of age), father's and mother's schooling (elementary, secondary and university), employment status (working or not working), skin color (white and non-white [mulatto, black, yellow and indigenous]) and economic class (Methodology of the Brazilian Association of Research Companies $\mathrm{ABEP}^{11}$, using the following categories: class $\mathrm{A} / \mathrm{B}$ and class $\mathrm{C} / \mathrm{D} / \mathrm{E})$.

Attendance in PE classes was measured by the question "How many PE classes do you attend during a normal week?" The answer options were: I don't have physical education classes; I do not participate in classes; 1 class per week; 2 lessons per week and; > 3 classes per week. This variable was categorized as follows: none, one class per week and two or more classes per week (kappa coefficient $=0,90)$.

Physical activity was measured by a questionnaire that presented high levels of reproducibility (ICC = 0.88; 95\%CI: 0.84-0.91) and moderate levels of validity $(\text { rho }=0.61 ; \mathrm{p}<0.01)^{12}$. The students provided information on the frequency (days/week) and duration 
(minutes/day) of moderate to vigorous physical activities engaged in for at least 10 minutes a day, during the week preceding data collection. Physical activity level was determined by adding the products of time and frequencies, resulting in a score expressed as minutes per week. Students who engaged in 300 minutes or more per week were classified as physically active and the remainder as physically inactive ${ }^{13}$.

The measure of sedentary behavior consisted of questions regarding time (hours/day) spent by students watching television, using the computer or playing videogames, during the week (Monday to Friday) and on the weekend (Saturday or Sunday). The weighted mean was calculated by multiplying the number of hours of sedentary behavior on weekdays by five and by two for weekends, adding to two amounts and dividing the result by seven to obtain the average number of hours per day. This variable was categorized as follows: $\leq 2 \mathrm{~h} /$ day and $>2 \mathrm{~h} /$ day of sedentary behavior ${ }^{14}$.

The following correlated factors of physical activity were measured: self-efficacy, attitude, perceived risks and benefits of physical activity. Self-efficacy for physical activity and the perceived risks and benefits were measured by 10 and 12-item scales, respectively, with a four-point Likert scale (ranging from strongly disagree $=1$ to strongly agree $=4)$. Attitude toward physical activity was measured by a five-item scale based on a four-point semantic differential scale. All the scales were previously validated ${ }^{15}$. A score was calculated using the mean value of the sum of the items on each scale for each of the correlated factors, and for the purpose of analysis, tertiles of these variables were calculated and categorized as low ( $1^{\text {st }}$ and $2^{\text {nd }}$ tertile) and high ( $3^{\text {rd }}$ tertile).

Nutritional status was assessed by body mass in$\operatorname{dex}\left(B M I=\right.$ body mass $[\mathrm{kg}] /$ height $\left.[\mathrm{m}]^{2}\right)$, based on self-reported measures of body mass and height. $\mathrm{Nu}-$ tritional status classification followed the criteria suggested by Cole et al. ${ }^{16}$, grouping students into no excess body weight (low weight + normal weight) and excess body weight (overweigh + obesity). Perceived health status was measured by the question 'How do you classify your health status' (poor, fair, good, very good, excellent). Next, these response categories were grouped into negative (poor, fair) and positive health perception (good, very good, excellent).

Mean, standard deviation and 95\% confidence interval $(95 \% \mathrm{CI})$ were used to describe numerical variables and relative and absolute frequency distribution
(\%) for categorical variables. The chi-square test for heterogeneity was applied to compare the proportion of students in PE classes according sociodemographic characteristics, correlates of physical activity, physical activity level, sedentary behavior, nutritional status and perceived health status.

Binary logistic regression was used to assess the crude and adjusted association between attendance in $\mathrm{PE}$ classes (no class/week $=0$; one class $/$ week $=1$; two or more classes/week $=2$ ) and the dependent variables (physical activity: physically active $=1$ and physically inactive $=0$; sedentary behavior: $\leq 2$ hours/day $=1$ and $>2$ hours $/$ day $=0$; self-efficacy: high $=1$ and low $=0$; at titude: high = 1 and low = 0; risks: not perceived $=1$ and perceived $=0$; benefits: perceived $=1$ and not perceived = 0 ; nutritional status: no excess body weight $=1$ and excess body weight $=0$; and perceived health: positive $=1$ and negative $=0$ ). In multivariate analysis all the independent variables were maintained in the model regardless of p-value. Analyses were stratified by type of school (public vs private), given that this variable exhibited significant interaction with the variables sex, age, school grade, parents schooling, economic class, skin color, employment status and perceived health status. Potential confounding factors were: sex, age, economic class, school grade and skin color. Statistical analyses were conducted in Stata 11.0 software. A 5\% significance level was adopted for the two-tailed tests.

The study was approved by the Ethics Committee of the Federal University of Paraiba (Protocol 0062/2009). All adolescents younger than 18 years of age were given permission to take part in the study by their mother/father/legal guardian and those 18 years and older gave their informed consent.

\section{Results}

A total of 3,220 students were interviewed, 231 were excluded due $<14$ or $>19$ years of age, 105 did not provide their age, five had some physical disability that limited or impeded their engaging in physical activity, and five did not respond adequately to the questionnaire (many unanswered questions). The final sample consisted of 2,874 students (850 from private schools and 2,024 from public schools) - losses and refusals totaled $17.8 \%$ of the cases. A posteriori calculation demonstrated that sample size of students from private schools had a power of $80 \%$ to detect an odds ratios greater than or equal to 1.41 as significant with prevalence of outcome between $54.5 \%$ and $75.0 \%$ (among 
the exposed) and between $46.5 \%$ and $67.7 \%$ among the unexposed. Among public schools, the sample size had $80 \%$ power to detect odds ratios greater than or equal to 1.26 as significant with prevalence of outcome between $42.7 \%$ and $72.9 \%$ (among the exposed) and between $37.2 \%$ and $67.8 \%$ among the unexposed.

The largest proportion of students was from public schools (70.4\%), girls (57.8\%), aged between 16 and 19 years (60.7\%), belonging to the lower economic classes (C/D/E: 54.2\%), whose parents had elementary schooling (fathers: $50.0 \%$ and mothers: $48.9 \%$ ) and who were not working (86.9\%). Information on physical activity level, nutritional status, perceived health, sedentary behavior and correlated factors of physical activity are described in Table 1 .

The proportion of students who reported to participate two or more PE classes per week was $41.9 \%$ (95\%CI: 40.1 - 43.7), with significantly higher proportions in public schools (56.8\%; 95\%CI: $54.6-59.0)$ when compared to private institutions $(6.6 \%$; $95 \% \mathrm{CI}$ : $4.9-8.2 ; p<0.001)$ - Figure 1.

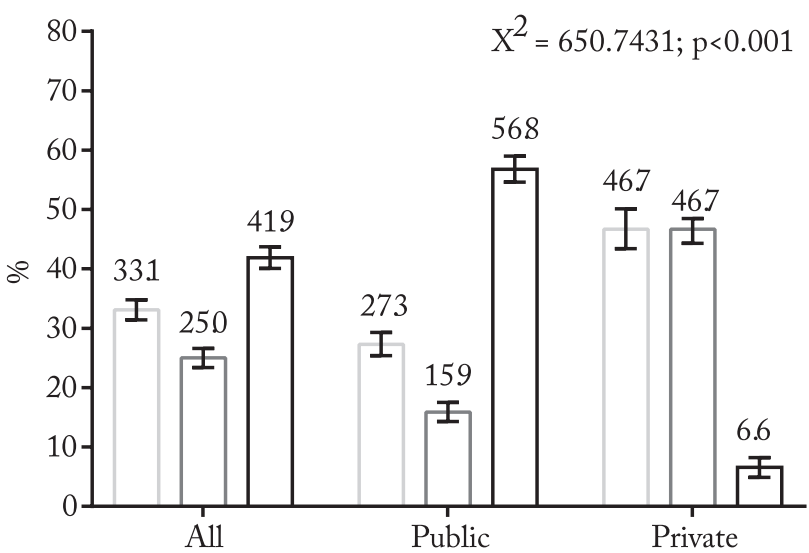

$\square$ no class/week $\square$ one classe/week $\square$ two or more classes/week

Figure 1 - Frequency of participation in Physical Education classes among public and private high school students, João Pessoa, Paraíba, Brazil, 2009 ( $\mathrm{n}=2,874$ students)

There was a higher proportion of boys attending two or more PE classes in both school systems. Higher attendance in PE classes was observed in older students (16-19 years old) and those in grades 1 and 2 of high school from private schools, and in younger students (14-15 years old), those whose parents had more schooling (high school or university), belonged to a high economic class (A/B) and did not work from public institutions (Table 2). The adolescents from both schools systems, who had the highest attitude and were physically active, and those from the public schools who had the highest self-efficacy and positive health perception, had a higher proportion of attending two or more PE classes (Figure 2).

Crude logistic regression showed a significant association between student attendance in two or more PE classes and a positive attitude toward physical activity, higher levels of physical activity and positive health perception among students from both public and private schools.

In adjusted analyses at private schools, students that attended two or more $\mathrm{PE}$ classes per week reported more positive attitudes $(\mathrm{OR}=3.07 ; 95 \% \mathrm{CI}: 1.07-8.83)$ and being more physically active $(\mathrm{OR}=2.69 ; 95 \% \mathrm{CI}: 1.16$ - 6.24) that those who did not. At public schools, those who attended two or more PE classes per week were more physically active $(\mathrm{OR}=2.20 ; 95 \% \mathrm{CI}: 1.66-2.91)$ $67 \%$ and $48 \%$ more likely to exhibit highly positive attitudes and positive health perception, respectively compared to those who attended no classes (Table 3).

\section{Discussion}

Attendance in PE classes was generally low, particularly at private schools, girls and older students. Those who attended these classes more frequently had more positive attitudes toward physical activity, higher levels of it and a higher positive health perception.

The prevalence of attending two or more PE classes observed in the present study was low (41.9\%), lower compared with other studies in United States $(81.6 \%)^{17}$ and Canada $(76.8 \%)^{18}$, as well as studies in Santa Catarina state $(48.1 \%)^{5}$, Paraná state $(78.9 \%)^{19}$ and São Paulo city $(49.5)^{6}$. However, it was higher than studies that were performed with high school students in Pernambuco state $\left(35.15^{4} \text { to } 37.6 \%\right)^{20}$. Data from the 2015 National Student Health Survey (PeNSE) ${ }^{21}$ of $9^{\text {th }}$ grade elementary students in 27 Brazilian state capitals found that $48.0 \%$ attended two or more PE classes per week, with the highest prevalence obtained in Santa Catarina (87.2\%) and lowest in the Para (15.9\%). In João Pessoa (Paraíba), PeNSE data showed that 47.2\% of students attended two or more PE classes per week, indicating that attendance tends to decline as children progress to higher grades of elementary education ${ }^{21}$.

The UNESCO report ${ }^{3}$ of a worldwide survey on PE classes revealed a set of administrative (absence of political incentives for mandatory PE classes in school curriculums; lack of investment in teacher training and development), environmental (adequate class facilities, equipment and resources) and social factors (lack of strategic partnerships with the community) as determinants for the 
Table 1 - Characteristics of students sample from João Pessoa, Paraíba, Brazil, 2009

\begin{tabular}{|c|c|c|c|c|c|c|}
\hline \multirow[t]{2}{*}{ Characteristics } & \multicolumn{2}{|c|}{$\begin{array}{l}\text { Private } \\
(\mathrm{n}=850)\end{array}$} & \multicolumn{2}{|c|}{$\begin{array}{c}\text { Public } \\
(\mathrm{n}=2,024)\end{array}$} & \multicolumn{2}{|c|}{$\begin{array}{c}\text { All } \\
(\mathrm{n}=2,874)\end{array}$} \\
\hline & $\mathrm{n}$ & $(\%)$ & $\mathrm{n}$ & $(\%)$ & $\mathrm{n}$ & $(\%)$ \\
\hline \multicolumn{7}{|l|}{ Sex } \\
\hline Male & 384 & 45.3 & 822 & 40.9 & 1,206 & 42.2 \\
\hline Female & 464 & 54.7 & 1,189 & 59.1 & 1,653 & 57.8 \\
\hline \multicolumn{7}{|l|}{ Age in years } \\
\hline $14-15$ & 403 & 47.4 & 725 & 35.8 & 1,128 & 39.3 \\
\hline $16-19$ & 447 & 52.6 & 1,299 & 64.2 & 1,746 & 60.7 \\
\hline \multicolumn{7}{|l|}{ Skin color } \\
\hline White & 364 & 43.0 & 566 & 28.1 & 930 & 32.5 \\
\hline Non-white & 483 & 57.0 & 1,446 & 71.9 & 1,929 & 67.5 \\
\hline \multicolumn{7}{|l|}{ Grade of high school } \\
\hline $1^{\mathrm{a}}$ & 307 & 36.1 & 773 & 38.2 & 1,080 & 37.6 \\
\hline $2^{\mathrm{a}}$ & 265 & 31.2 & 688 & 34.0 & 953 & 33.2 \\
\hline $3^{\mathrm{a}}$ & 278 & 32.7 & 563 & 27.8 & 841 & 29.2 \\
\hline \multicolumn{7}{|l|}{ Economic class } \\
\hline $\mathrm{A} / \mathrm{B}$ & 685 & 89.4 & 476 & 26.9 & 1,161 & 45.8 \\
\hline $\mathrm{C} / \mathrm{D} / \mathrm{E}$ & 81 & 10.6 & 1,291 & 73.1 & 1,372 & 54.2 \\
\hline \multicolumn{7}{|l|}{ Father's schooling } \\
\hline Elementary & 147 & 17.5 & 1,244 & 64.0 & 1,391 & 50.0 \\
\hline Secundary & 315 & 37.6 & 580 & 29.8 & 895 & 32.2 \\
\hline University & 377 & 44.9 & 120 & 6.2 & 497 & 17.8 \\
\hline \multicolumn{7}{|l|}{ Mother's schooling } \\
\hline Elementary & 125 & 14.8 & 1,266 & 63.3 & 1,391 & 48.9 \\
\hline Secundary & 317 & 37.5 & 859 & 29.4 & 906 & 31.8 \\
\hline University & 404 & 47.7 & 146 & 7.3 & 550 & 19.3 \\
\hline \multicolumn{7}{|l|}{ Employment status } \\
\hline Working & 50 & 6.1 & 316 & 15.9 & 366 & 13.1 \\
\hline Not working & 769 & 93.9 & 1,667 & 84.1 & 2,436 & 86.9 \\
\hline \multicolumn{7}{|l|}{ Attitude } \\
\hline High & 590 & 70.6 & 1,339 & 68.8 & 1,929 & 69.3 \\
\hline Low & 246 & 29.4 & 608 & 31.2 & 854 & 30.7 \\
\hline \multicolumn{7}{|l|}{ Self-efficacy } \\
\hline High & 553 & 68.2 & 1,210 & 66.1 & 1,763 & 66.7 \\
\hline Low & 258 & 31.8 & 622 & 33.9 & 880 & 33.3 \\
\hline \multicolumn{7}{|l|}{ Risks } \\
\hline Perceived & 279 & 33.9 & 691 & 36.7 & 970 & 35.8 \\
\hline Not perceived & 545 & 66.1 & 1,192 & 63.3 & 1,737 & 64.2 \\
\hline \multicolumn{7}{|l|}{ Benefits } \\
\hline Not perceived & 266 & 32.4 & 593 & 31.1 & 859 & 31.5 \\
\hline Perceived & 555 & 67.6 & 1,314 & 68.9 & 1,869 & 68.5 \\
\hline \multicolumn{7}{|l|}{ Physical activity } \\
\hline Physically active & 410 & 48.2 & 1,020 & 50.4 & 1,430 & 49.8 \\
\hline Physically inactive & 440 & 51.8 & 1,004 & 49.6 & 1,444 & 50.2 \\
\hline \multicolumn{7}{|l|}{ Sedentary behavior } \\
\hline$\leq 2$ hours/day & 59 & 7.0 & 283 & 14.3 & 342 & 12.1 \\
\hline$>2$ hours/day & 785 & 93.0 & 1,701 & 85.7 & 2,486 & 87.9 \\
\hline \multicolumn{7}{|l|}{ Nutritional status } \\
\hline Excess body weight & 132 & 16.5 & 221 & 11.8 & 353 & 13.2 \\
\hline No excess body weight & 666 & 83.5 & 1,655 & 88.2 & 2,321 & 86.8 \\
\hline Perceived health & & & & & & \\
\hline Negative & 100 & 12.0 & 349 & 17.5 & 449 & 15.8 \\
\hline Positive & 737 & 88.0 & 1,648 & 82.5 & 2,385 & 84.2 \\
\hline
\end{tabular}


Table 2 - Attendance in Physical Education classes among public and private high school students according sociodemographic characteristics, João Pessoa, Paraíba, Brazil, 2009

\begin{tabular}{|c|c|c|c|c|c|c|c|c|c|c|c|c|c|c|}
\hline \multirow{3}{*}{ Variables } & \multicolumn{7}{|c|}{ Private } & \multicolumn{7}{|c|}{ Public } \\
\hline & \multicolumn{2}{|c|}{$\begin{array}{c}\text { No } \\
\text { class/week }\end{array}$} & \multicolumn{2}{|c|}{$\begin{array}{c}\text { One } \\
\text { class/week }\end{array}$} & \multicolumn{2}{|c|}{$\begin{array}{l}\text { Two or more } \\
\text { classes/week }\end{array}$} & \multirow[t]{2}{*}{$\mathrm{p}^{*}$} & \multicolumn{2}{|c|}{$\begin{array}{c}\text { No } \\
\text { class/week }\end{array}$} & \multicolumn{2}{|c|}{$\begin{array}{c}\text { One } \\
\text { class/week }\end{array}$} & \multicolumn{2}{|c|}{$\begin{array}{l}\text { Two or more } \\
\text { classes/week }\end{array}$} & \multirow[t]{2}{*}{$\mathrm{p}^{*}$} \\
\hline & $\mathrm{n}$ & $\%$ & $\mathrm{n}$ & $\%$ & $\mathrm{n}$ & $\%$ & & $\mathrm{n}$ & $\%$ & $\mathrm{n}$ & $\%$ & $\mathrm{n}$ & $\%$ & \\
\hline Sex & & & & & & & 0.013 & & & & & & & 0.001 \\
\hline Male & 167 & 43.7 & 180 & 47.1 & 35 & 9.2 & & 201 & 24.7 & 90 & 11.1 & 522 & 64.2 & \\
\hline Female & 226 & 49.2 & 213 & 46.4 & 20 & 4.4 & & 340 & 28.8 & 227 & 19.3 & 612 & 51.9 & \\
\hline Age in years & & & & & & & 0.001 & & & & & & & 0.001 \\
\hline $14-15$ & 144 & 36.0 & 230 & 57.5 & 26 & 6.5 & & 122 & 17.0 & 130 & 18.1 & 466 & 64.9 & \\
\hline $16-19$ & 250 & 56.4 & 164 & 37.0 & 29 & 6.6 & & 426 & 33.2 & 188 & 14.6 & 671 & 52.2 & \\
\hline Grade of high school & & & & & & & 0.001 & & & & & & & 0.228 \\
\hline $1^{\mathrm{a}}$ & 102 & 33.4 & 182 & 59.7 & 21 & 6.9 & & 195 & 25.6 & 135 & 17.7 & 433 & 56.7 & \\
\hline $2^{\mathrm{a}}$ & 115 & 43.7 & 131 & 49.8 & 17 & 6.5 & & 200 & 29.4 & 93 & 13.7 & 387 & 56.9 & \\
\hline $3^{\mathrm{a}}$ & 177 & 64.4 & 81 & 29.4 & 17 & 6.2 & & 153 & 27.3 & 90 & 16.1 & 317 & 56.6 & \\
\hline Father's schooling & & & & & & & 0.645 & & & & & & & 0.017 \\
\hline Elementary & 71 & 48.3 & 66 & 44.9 & 10 & 6.8 & & 357 & 29.0 & 204 & 16.6 & 670 & 54.4 & \\
\hline Secundary & 148 & 47.6 & 139 & 44.7 & 24 & 7.7 & & 142 & 24.7 & 78 & 13.5 & 356 & 61.8 & \\
\hline University & 168 & 44.9 & 185 & 49.5 & 21 & 5.6 & & 24 & 20.2 & 22 & 18.5 & 73 & 61.3 & \\
\hline Mother's schooling & & & & & & & 0.113 & & & & & & & 0.119 \\
\hline Elementary & 66 & 53.2 & 51 & 41.1 & 7 & 5.7 & & 358 & 28.6 & 207 & 16.6 & 686 & 54.8 & \\
\hline Secundary & 131 & 41.7 & 157 & 50.0 & 26 & 8.3 & & 152 & 26.0 & 81 & 13.8 & 352 & 60.2 & \\
\hline University & 196 & 48.9 & 184 & 45.9 & 21 & 5.2 & & 32 & 22.1 & 27 & 18.6 & 86 & 59.3 & \\
\hline Economic class & & & & & & & 0.076 & & & & & & & 0.028 \\
\hline $\mathrm{A} / \mathrm{B}$ & 305 & 44.9 & 329 & 48.5 & 45 & 6.6 & & 126 & 26.7 & 57 & 12.1 & 289 & 61.2 & \\
\hline $\mathrm{C} / \mathrm{D} / \mathrm{E}$ & 47 & 58.0 & 29 & 35.8 & 5 & 6.2 & & 351 & 27.5 & 216 & 16.9 & 710 & 55.6 & \\
\hline Skin color & & & & & & & 0.375 & & & & & & & 0.763 \\
\hline White & 160 & 44.5 & 178 & 49.4 & 22 & 6.1 & & 147 & 26.2 & 89 & 15.9 & 324 & 57.9 & \\
\hline Non-white & 233 & 48.5 & 214 & 44.6 & 33 & 6.9 & & 398 & 27.8 & 228 & 15.9 & 805 & 56.3 & \\
\hline Employment status & & & & & & & 0.230 & & & & & & & 0.001 \\
\hline Working & 29 & 58.0 & 18 & 36.0 & 3 & 6.0 & & 145 & 46.3 & 21 & 6.7 & 147 & 47.0 & \\
\hline Not working & 348 & 45.7 & 364 & 47.8 & 50 & 6.5 & & 394 & 23.9 & 288 & 17.4 & 968 & 58.7 & \\
\hline
\end{tabular}

*Chi-square test for heterogenity

nonexistence or low attendance of students in PE classes.

In many cases, these classes have been characterized by repetitive content, involving practicing basic sport principles and executing technical movements, but without a logical sequence, disconnected from the pedagogic aims of each grade, as well as from students' needs and expectations. This could be referred to as 'exercise for the sake of it'. Aspects such as scarce of safe, accessible, well maintained facilities ${ }^{22}$, lack PE practices for minorities and people with disabilities, absence of clear definitions regarding contents and their seriation over the course of schooling, lack of strategic partnerships with the wider community, nonexistence of monitoring and quality control systems for $\mathrm{PE}^{3}$, large number of requests to miss class ${ }^{23}$, lack of teacher's motivation and empowerment, and low social and finan- cial recognition of teachers ${ }^{24}$ are factors that may help explain the poor attendance in PE classes in Brazil.

The lower class attendance in the Northeast of the country may be due the poor conditions for engaging in sports and physical activity because of low investment in facilities (gymnasiums and soccer fields) and materials (balls, cones, hoops, among others) ${ }^{22}$. Higher attendance among public school students can be explained by the fact that $\mathrm{PE}$ classes are optional in the vast majority of private institutions ${ }^{5}$. This is owing to the priority given to preparing students for university entrance examinations.

As observed in other studies ${ }^{7,19}$, the attendance rate $\mathrm{PE}$ classes was higher in boys. This finding can be explained by the predominance of sport contents in the classes $^{20}$, given that boys prefer sport activities requiring 
a)

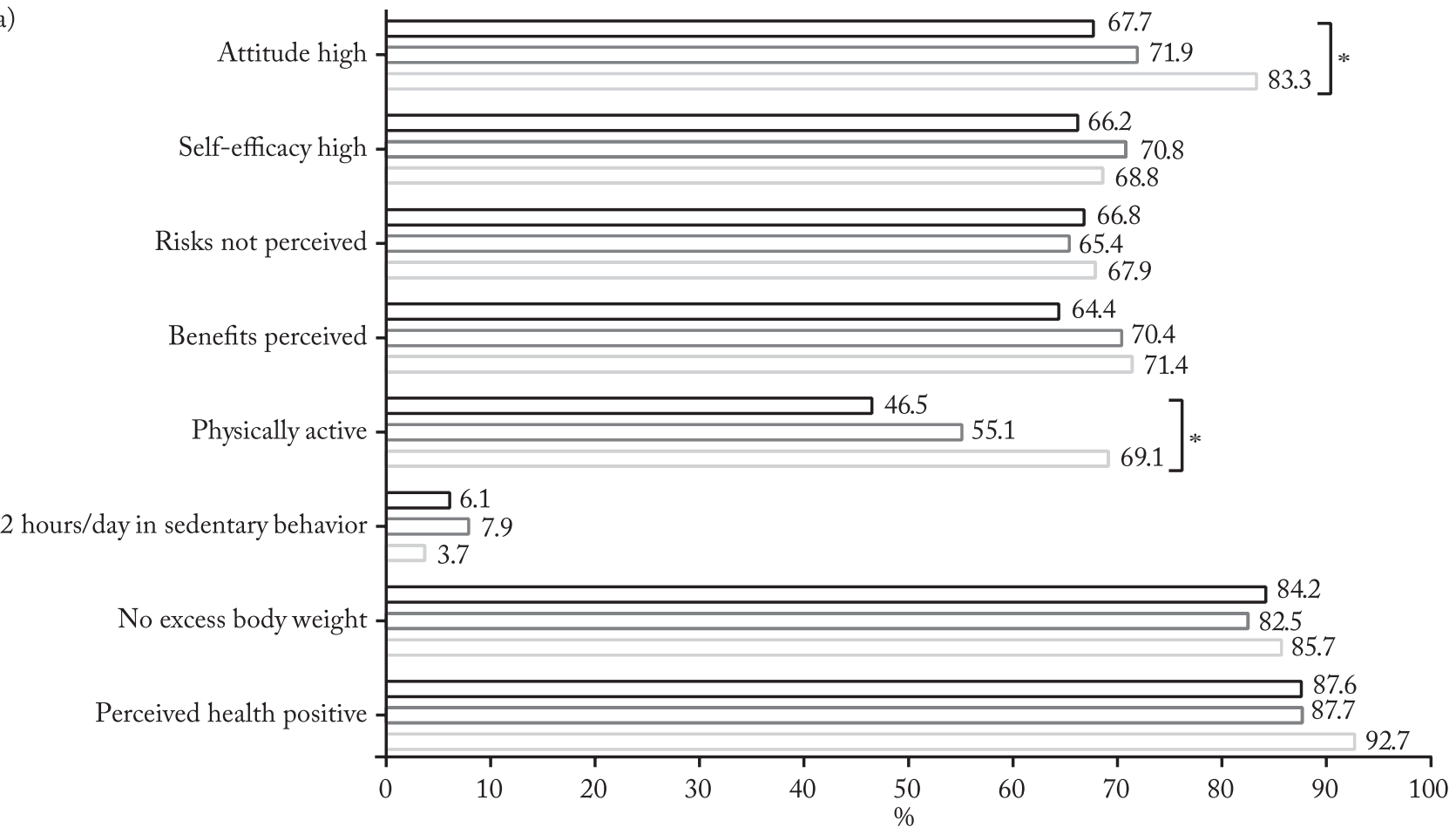

b)

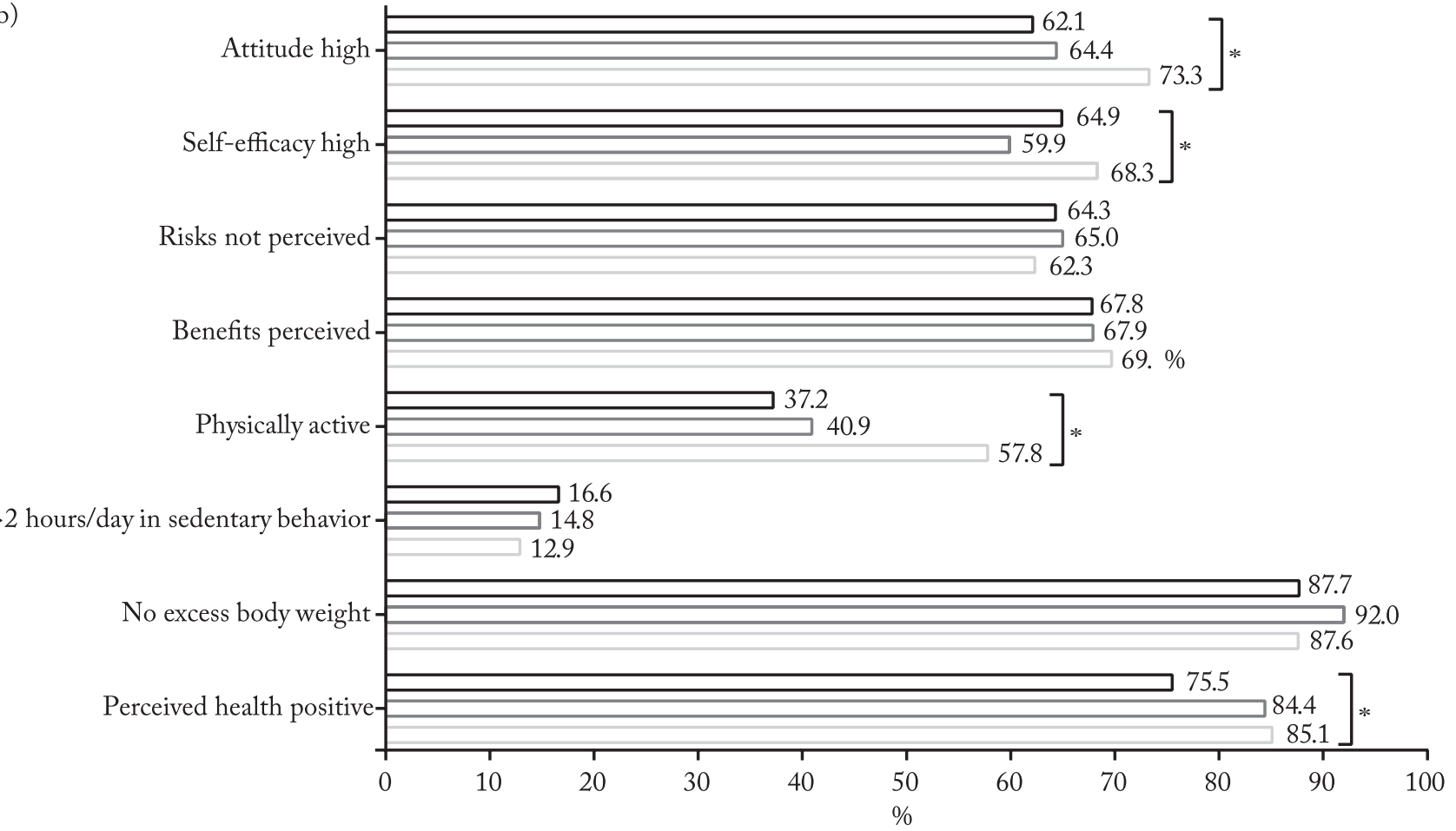

$\square$ no class/week $\square$ one classe/week $\square$ two or more classes/week

Figure 2 - Attendance in Physical Education classes among private (a) and public (b) high school students according physical activity correlates, physical activity level, sedentary behavior, nutritional status and perceived health status, João Pessoa, Paraíba, Brazil, 2009

* Chi-square test for heterogenity $=p<0.05$

physical strength and competitiveness, while girls would rather take part in physical activities involving emotion- al and social skills, characteristics scarcely investigated in PE classes ${ }^{25}$. Since the classes are given during class 
Table 3 - Binary logistic regression analyses to crude and adjusted association between attendance in Physical Education classes and physical activity correlates, physical activity level, sedentary behavior, nutritional status and perceived health status in students from João Pessoa, Paraíba, Brazil, 2009

\begin{tabular}{|c|c|c|c|c|c|c|c|c|}
\hline \multirow{2}{*}{$\begin{array}{l}\text { Frequency of attendance in PE } \\
\text { classes }\end{array}$} & Attitude & Self-efficacy & Risks & Benefits & $\begin{array}{c}\text { Physical } \\
\text { activity level }\end{array}$ & $\begin{array}{c}\text { Sedentary } \\
\text { behavior }\end{array}$ & $\begin{array}{l}\text { Nutritional } \\
\text { status }\end{array}$ & $\begin{array}{c}\text { Perceived } \\
\text { health status }\end{array}$ \\
\hline & $\begin{array}{c}\mathrm{OR} \\
(95 \% \mathrm{CI})\end{array}$ & $\begin{array}{c}\mathrm{OR} \\
(95 \% \mathrm{CI})\end{array}$ & $\begin{array}{c}\mathrm{OR} \\
(95 \% \mathrm{CI})\end{array}$ & $\begin{array}{c}\mathrm{OR} \\
(95 \% \mathrm{CI})\end{array}$ & $\begin{array}{c}\mathrm{OR} \\
(95 \% \mathrm{CI})\end{array}$ & $\begin{array}{c}\mathrm{OR} \\
(95 \% \mathrm{CI})\end{array}$ & $\begin{array}{c}\text { OR } \\
(95 \% \mathrm{CI})\end{array}$ & $\begin{array}{c}\mathrm{OR} \\
(95 \% \mathrm{CI})\end{array}$ \\
\hline \multicolumn{9}{|l|}{ Private schools } \\
\hline \multicolumn{9}{|l|}{ Crude analyses } \\
\hline One class/week & $\begin{array}{c}1.22 \\
(0.90-1.66)\end{array}$ & $\begin{array}{c}1.24 \\
(0.91-1.68)\end{array}$ & $\begin{array}{c}0.94 \\
(0.69-1.26)\end{array}$ & $\begin{array}{c}1.31 \\
(0.97-1.78)\end{array}$ & $\begin{array}{c}1.41 \\
(1.07-1.87)\end{array}$ & $\begin{array}{c}1.11 \\
(0.76-1.63)\end{array}$ & $\begin{array}{c}0.88 \\
(0.60-1.30)\end{array}$ & $\begin{array}{c}1.01 \\
(0.66-1.55)\end{array}$ \\
\hline Two or more class/week & $\begin{array}{c}2.39 \\
(1.13-5.03)\end{array}$ & $\begin{array}{c}1.12 \\
(0.59-2.09)\end{array}$ & $\begin{array}{c}1.05 \\
(0.57-1.94)\end{array}$ & $\begin{array}{c}1.38 \\
(0.72-2.65)\end{array}$ & $\begin{array}{c}2.58 \\
(1.41-4.72)\end{array}$ & $\begin{array}{c}0.71 \\
(0.29-1.73)\end{array}$ & $\begin{array}{c}1.13 \\
(0.48-2.63)\end{array}$ & $\begin{array}{c}1.81 \\
(0.63-5.23)\end{array}$ \\
\hline \multicolumn{9}{|l|}{ Adjusted analyses* } \\
\hline One class/week & $\begin{array}{c}1.14 \\
(0.76-1.71)\end{array}$ & $\begin{array}{c}1.03 \\
(0.71-1.51)\end{array}$ & $\begin{array}{c}1.85 \\
(0.75-1.57)\end{array}$ & $\begin{array}{c}1.36 \\
(0.92-2.00)\end{array}$ & $\begin{array}{c}1.34 \\
(0.94-1.91)\end{array}$ & $\begin{array}{c}1.23 \\
(0.79-1.92)\end{array}$ & $\begin{array}{c}0.77 \\
(0.47-1.24)\end{array}$ & $\begin{array}{c}0.95 \\
(0.56-1.62)\end{array}$ \\
\hline Two or more class/week & $\begin{array}{c}3.07 \\
(1.07-8.83)\end{array}$ & $\begin{array}{c}1.14 \\
(0.49-2.64)\end{array}$ & $\begin{array}{c}1.42 \\
(0.66-3.08)\end{array}$ & $\begin{array}{c}1.20 \\
(0.53-2.70)\end{array}$ & $\begin{array}{c}2.69 \\
(1.16-6.24)\end{array}$ & $\begin{array}{c}0.62 \\
(0.21-1.89)\end{array}$ & $\begin{array}{c}1.06 \\
(0.39-2.85)\end{array}$ & $\begin{array}{c}1.07 \\
(0.29-3.96)\end{array}$ \\
\hline \multicolumn{9}{|l|}{ Public schools } \\
\hline \multicolumn{9}{|l|}{ Crude analyses } \\
\hline One class/week & $\begin{array}{c}1.10 \\
(0.82-1.47)\end{array}$ & $\begin{array}{c}0.81 \\
(0.60-1.09)\end{array}$ & $\begin{array}{c}1.03 \\
(0.76-1.39)\end{array}$ & $\begin{array}{c}1.00 \\
(0.74-1.36)\end{array}$ & $\begin{array}{c}1.17 \\
(0.88-1.55)\end{array}$ & $\begin{array}{c}1.05 \\
(0.76-1.45)\end{array}$ & $\begin{array}{c}1.61 \\
(0.98-2.64)\end{array}$ & $\begin{array}{c}1.75 \\
(1.22-2.52)\end{array}$ \\
\hline Two or more class/week & $\begin{array}{c}1.67 \\
(1.34-2.08)\end{array}$ & $\begin{array}{c}1.17 \\
(0.93-1.46)\end{array}$ & $\begin{array}{c}0.92 \\
(0.73-1.14)\end{array}$ & $\begin{array}{c}1.09 \\
(0.87-1.36)\end{array}$ & $\begin{array}{c}2.31 \\
(1.87-2.85)\end{array}$ & $\begin{array}{c}0.83 \\
(0.65-1.06)\end{array}$ & $\begin{array}{c}0.99 \\
(0.72-1.37)\end{array}$ & $\begin{array}{c}1.86 \\
(1.44-2.40)\end{array}$ \\
\hline \multicolumn{9}{|l|}{ Adjusted analyses * } \\
\hline One class/week & $\begin{array}{c}1.22 \\
0.81-1.82\end{array}$ & $\begin{array}{c}0.69 \\
(0.47-1.00)\end{array}$ & $\begin{array}{c}1.08 \\
(0.74-1.58)\end{array}$ & $\begin{array}{c}0.96 \\
(0.64-1.43)\end{array}$ & $\begin{array}{c}1.32 \\
(0.91-1.93)\end{array}$ & $\begin{array}{c}0.89 \\
(0.58-1.37)\end{array}$ & $\begin{array}{c}1.05 \\
(0.57-1.94)\end{array}$ & $\begin{array}{c}1.79 \\
(1.10-2.90)\end{array}$ \\
\hline Two or more class/week & $\begin{array}{c}1.67 \\
1.23-2.28\end{array}$ & $\begin{array}{c}1.01 \\
(0.76-1.36)\end{array}$ & $\begin{array}{c}1.07 \\
(0.80-1.42)\end{array}$ & $\begin{array}{c}1.02 \\
(0.75-1.39)\end{array}$ & $\begin{array}{c}2.20 \\
(1.66-2.91)\end{array}$ & $\begin{array}{c}0.81 \\
(0.59-1.13)\end{array}$ & $\begin{array}{c}0.82 \\
(0.53-1.26)\end{array}$ & $\begin{array}{c}1.48 \\
(1.04-2.11)\end{array}$ \\
\hline
\end{tabular}

$\mathrm{PE}=$ Physical Education; Reference: no class/week; *Adjusted for sex, age, economic class, skin color, grade of high school and other dependents variables without model analyzed as in the dependent variables

time, some of the girls may not participate for esthetic reasons, assuming that perspiring during these activities will ruin/mess up their hair and make-up.

As with Feitosa et al. ${ }^{20}$, who studied high school students from Caruaru, Pernambuco state, the present investigation found a significant reduction in PE class attendance as students progressed to higher secondary school grades. This behavior may be related to the fact that at most schools, attending these classes is not a priority and the time that could be spent on this discipline is used to prepare students for university entrance examinations. As a result, expectations regarding $\mathrm{PE}$ are a matter of secondary importance.

In the present study, public students whose parents had a higher schooling level and better economic class (Class A/B) attended more PE classes. Parents who belong to higher socioeconomic strata could better afford to enroll their children in well-structured schools, provide more social support for engaging in physical activity ${ }^{26}$, and encourage them to participate more in physical activities, especially at school ${ }^{7}$. Taken together, these factors lead to greater student attendance in PE classes.
It was found that students who reported higher attendance in $\mathrm{PE}$ classes were more likely to follow recommendations regarding physical activities, reinforcing the findings of earlier studies ${ }^{4,13}$. Adolescents who are more physically active outside the school setting may be more interested in attending PE classes because they feel more able to engage in physical activities (greater perceived self-efficacy), and value their importance (more favorable attitudes toward engaging in physical activities $)^{7,10}$. However, PE classes may represent an important part of weekly physical activities. In some cases, it may be the primary or only opportunity for students to participate in regular physical activity ${ }^{27}$.

Students who attended more PE classes were likely to have more favorable attitudes toward engaging in physical activity. Some studies suggest that greater attendance in $\mathrm{PE}$ classes is directly associated with positive attitudes toward physical activity ${ }^{1,28}$. One explanation for this result is that students who attend PE classes have higher levels of knowledge of and interest in physical activity, leading to more positive attitudes ${ }^{10}$.

Public students who attended more PE classes were 
more likely to exhibit positive perceived health compared to those who did not participate. Adolescents who attended more PE classes were probably the most physically active and thus displayed positive health perception and may have been more exposed to health-related issues in $\mathrm{PE}$ classes. $\mathrm{PE}$ classes have been considered important in promoting healthy eating habits, physical activity and greater perception of its benefits ${ }^{3}$.

A systematic review of intervention studies ${ }^{29}$ carried out in Latin America demonstrated that interventions to promote physical activity at school are more effective when they involve actions developed in PE classes (for example, small changes in the content taught and the use of instructional teaching resources). These findings show that if high-quality classes are given, they can play an important role in promoting physical activity. Starting from the principle that PE classes are favorable to changing behavior ${ }^{5}$, this discipline acts as an important educational agent for students to adopt a physically active and healthy lifestyle.

The main limitations of this study include: its cross-sectional nature, precluding establishing a cause-effect relationship between attending PE classes and associated factors (attitudes toward physical activity, levels of activity, perceived health status). The following are strengths: it considered the weekly attendance in PE classes, not limiting itself to dichotomous outcomes, as do the majority of studies (attend vs do not attend $d^{7,19,20}$; is representative of the sample of public and private school students, since most studies have only involved the former ${ }^{7,19,20}$.

It can be concluded that high school student attendance in PE classes was low, particularly at private schools, girls and older students (at both public and private institutions), as well as those belonging to economic classes $\mathrm{C}, \mathrm{D}$ and $\mathrm{E}$ (public schools). Attending two or more PE classes per week was a favorable aspect for engaging in physical activity (higher levels and more favorable attitudes) and positive health perception.

These results may help create future school-based strategies that seek to make society, authorities, directors and family members aware of the importance of $\mathrm{PE}$ in order to improve the quality of these classes and student attendance ${ }^{3}$, mainly because it may contribute to higher levels of physical activity, positive health perception and positive attitudes toward exercise.

\section{Conflicts of interest}

The authors declare no conflict of interest.

\section{Acknowledgment}

We would like to thank Coordenação de Aperfeiçoamento de Pessoal de Nível Superior (CAPES), for study and research grants.

\section{Authors' contributions}

Prazeres Filho A, participated in the conception and writing of the manuscript, analysis and interpretation of the data. Mendonça G, Souza Neto JM, Silva ABP participated in the writing and critical analysis of the manuscript and data analysis. Tassitano RM participated in the critical review of the manuscript. Farias JC Junior, participated in all stages of construction of the manuscript.

\section{References}

1. Hardman CM, Barros SSH, Andrade MLSS, Nascimento JV, Nahas MV, Barros MVG. Participation in physical education classes and indicators of attitudes toward physical activity in adolescents. Rev Bras Educ Fis Esporte. 2013;27(4):623-31.

2. BRASIL. Law n. $9394 / 96$ of 20 December 1996. Law of guidelines and bases for national education. Brasília; 1996. [citado em 2019 ago 11]. Disponível em: https://www2. senado.leg.br/bdsf/bitstream/handle/id/70320/65.pdf.

3. UNESCO. Diretrizes em educação física de qualidade (EFQ) para gestores de políticas. UNESCO: Brasília; 2015. [citado em 2019 ago 11]. Disponível em: https:// unesdoc.unesco. org/ ark:/48223/pf0000231963.

4. Tassitano RM, Barros MV, Tenório M, Bezerra J, Florindo AA, Reis RS. Enrollment in Physical Education Is Associated With Health-Related Behavior Among High School Students. J Sch Health. 2010;80(3):126-33.

5. Silva KS, Nahas MV, Peres KG, Lopes AS. Factors associated with physical activity, sedentary behavior, and participation in physical education among high school students in Santa Catarina State, Brazil. Cad Saude Publica. 2009;25(10):2187-200.

6. Ceschini FL, Andrade DR, Oliveira LC, Araújo Júnior JF, Matsudo VK. Prevalence of physical inactivity and associated factors among high school students from state's public schools. J Pediatr (Rio J). 2009;85(4):301-6.

7. Coledam DHC, Ferraiol PF, Pires Junior R, Santos JW, Oliveira AR. Factors associated with participation in sports and physical education among students from Londrina, Paraná State, Brazil. Cad Saude Publica. 2014;30(3):533-45.

8. Silva RJ, Silva DA, Oliveira AC. Low Physical Activity Levels and Associated Factors in Brazilian Adolescents From Public High Schools. J Phys Act Health. 2013;11:1438-45.

9. Costa BG, Silva KS, George AM, Assis MAA. Sedentary behavior during school-time: Sociodemographic, weight status, physical education class, and school performance correlates in Brazilian schoolchildren. J Sci Med Sport. 2017;20(1):70-4.

10. Sterdt E, Liersch S, Walter U. Correlates of physical activity of children and adolescents: A systematic review of reviews. Health Educ J. 2013;73(1):72-89.

11. Brazilian Association of Research Companies - ABEP. Brazil Economic Classification Criterion. ABEP; 2009. [citado em 2019 ago 11]. Disponível em: http://www. abep.org/new/ codigos Condutas.aspx.

12. Farias Júnior JC, Lopes AS, Mota J, Santos MP, Ribeiro JC, Hallal PC. Validity and reproducibility of a physical activity questionnaire for adolescents: adapting the SelfAdministered Physical Activity Checklist. Rev Bras Epidemiol. 2012;15(1):198-210. 
13. World Health Organization. Global recommendations on physical activity for health. WHO; 2010. [citado em 2019 ago 11]. Disponível em: https://apps.who.int/iris/bitstream / handle/10665/44399/9789241599979_eng.pdf?s.

14. Tremblay MS, LeBlanc AG, Janssen I, Kho ME, Hicks A, Murumets $\mathrm{K}$, et al. Canadian sedentary behaviour guidelines for children and youth. Appl Physiol Nutr Metab. 2011;36(1):59-64.

15. Farias Júnior JC, Lopes AS, Reis RS, Nascimento JV, Borgatto AF, Hallal PC. Development and validation of a questionnaire measuring factors associated with physical activity in adolescents. Rev Bras Saude Mater Infant. 2011;11(3):301-12.

16. Cole TJ, Bellizzi MC, Flegal KM, Dietz WH. Establishing a standard definition for child overweight and obesity worldwide: international survey. BMJ. 2000;320(7244):1240.

17. Loprinzi PD, Cardinal BJ, Cardinal MK, Corbin CB.Physical education and sport: Does participation relate to physical activity patterns, observed fitness, and personal attitudes and beliefs? Am J Health Promot. 2018;32(3):613-20.

18. Naiman DI, Leatherdale ST, Gotay C, Mâsse LC. School factors associated with the provision of physical education and levels of physical activity among elementary school students in Ontario. Can J Public Health. 2015;106(5):e290-e6.

19. Bacil E, Rech C, Hino A. Physical activity patterns among high school students of Ponta Grossa, PR. Rev Bras Ativ Fís Saúde. 2013;18(2):177-85.

20. Feitosa W, Tassitano R, Tenório M, Albuquerque A, Guimarães F, Lima Neto A. Physical education class on hifh scool in Caruaru's state public schools: compulsory curriculim component or an optional? Rev Educ Fís/UEM. 2011;22(1):97-109.

21. BRASIL. National School of Health Survey (PeNSE) 2015. Instituto Brasileiro de Geografia e Estatística - IBGE: Rio de Janeiro; 2016. [citado em 2019 ago 11]. Disponível em: https://biblioteca.ibge.gov.br/visualizacao/livros/liv97870.pdf.
22. Tenório MCM, Tassitano RM, Lima MC. Knowing the school environment for physical education classes: is there a difference between schools? Rev Bras Ativ Fís Saúde. 2013;17(4):307-13.

23. Souza Júnior OM, Darido SC. Attendance exemption in physical education classes: Showing the way to minimize the effects of an archaic legislation. Pensar Prát. 2009;12(2):1-12.

24. Tenório MCM, Lima MCO, Tassitano RM. Motivação de Professores e Estudantes Para as Aulas de Educação Física do Ensino Médio [Doctoral dissertation]: Universidade Federal de Pernambuco, Brasil; 2014.

25. Uchoga LAR, Altmann H. Educação física escolar e relações de gênero: diferentes modos de participar e arriscar-se nos conteúdos de aula. Rev Bras Cienc Esporte. 2016;38(2):163-70.

26. Mendonça G, Farias Júnior JC. Physical activity and social support in adolescents: analysis of different types and sources of social support. J Sports Sci. 2015:1-10.

27. Dauenhauer BD, Keating XD. The influence of physical education on physical activity levels of urban elementary students. Res QExerc Sport. 2011;82(3):512-20.

28. Bagøien TE, Halvari H, Nesheim H. Self-determined motivation in physical education and its links to motivation for leisure-time physical activity, physical activity, and wellbeing in general. Percept Mot Skills. 2010;111(2):407-32.

29. Hoehner CM, Soares J, Perez DP, Ribeiro IC, Joshu CE, Pratt $\mathrm{M}$, et al. Physical activity interventions in Latin America: a systematic review. Am J Prev Med. 2008;34(3):224-33.

Receipt: 24/05/2019

Approved: 09/11/2019

Quote this article as:

Prazeres Filho A, Mendonça G, Souza Neto JM, Tassitano RM, Silva ABP, Farias Júnior JC. Attendance in Physical Education classes and associated factors among high school students. Rev Bras Ati Fis Saúde. 2019;24:e0083. DOI: 10.12820/rbafs.24e0083 